\title{
Cryptococcus antarcticus sp. nov. and Cryptococcus albidosimilis sp. nov., Basidioblastomycetes from Antarctic Soils
}

\author{
H. S. VISHNIAC ${ }^{*}$ AND C. P. KURTZMAN ${ }^{2}$ \\ Department of Microbiology, Oklahoma State University, Stillwater, Oklahoma $74078,{ }^{1}$ and Microbial \\ Properties Research, National Center for Agricultural Utilization Research, Agricultural \\ Research Service, U.S. Department of Agriculture, Peoria, Illinois $61604^{2}$
}

\begin{abstract}
Cryptococcus albidus, which was described as having maximum growth temperatures $\left(T_{\max }\right)$ that vary from $<20$ to $>37^{\circ} \mathrm{C}$, is an apparent exception to van Uden's rule that yeast species generally comprise strains which have $T_{\max }$ that vary by not more than $5^{\circ} \mathrm{C}$. This exception is dealt with in this paper by the description of phenotypically similar species that have lower $T_{\max }$ than $C$. albidus and exhibit no significant DNA similarity to the type strain of $C$. albidus. Cryptococcus albidosimilis sp. nov., a mesophilic blastobasidiomycete that was isolated from soil of Linnaeus Terrace, Antarctica (type strain, strain MYSW A823-2Y761/70 [= ATCC 76863, $=$ CBS 7711, = NRRL Y-17463]), has a $T_{\max }$ of $30^{\circ} \mathrm{C}$ and a guanine-plus-cytosine content of $55 \mathrm{~mol} \%$. Cryptococcus antarcticus sp. nov. is a psychrophilic blastobasidiomycete (type strain, strain MYSW A81220bY693/64 [= ATCC 76663, = CBS 7687, = NRRL Y-17461]) is known only from soils of University Valley, Antarctica. $C$. antarcticus does not exhibit significant DNA similarity with $C$. albidosimilis, from which it differs phenotypically in its failure to assimilate lactose. The guanine-plus-cytosine content of $C$. antarcticus is 55 mol\%. This species includes four biotypes whose levels of DNA similarity are greater than $72 \%$. The $T_{\max }$ of these biotypes vary from $>15$ and $<20^{\circ} \mathrm{C}$ to $>20$ and $<25^{\circ} \mathrm{C}$. Both habitat temperature (reflected in fatty acid composition) and the sporadic availability of liquid water in University Valley apparently were factors in the evolution of this species.
\end{abstract}

van Uden (26) has called attention to the importance of temperature in yeast species identification, pointing out that the majority of yeast species comprised strains whose $T_{\max }$ vary by not more (usually less) than $5^{\circ} \mathrm{C}$. van Uden's rule apparently also holds for most of the psychrophilic or psychrotolerant basidiomycetous yeasts; the exceptions are the five most widely collected species (30). One of these organisms, Cryptococcus albidus (Saito) Skinner var. albi$d u s$, has been described $(1,3,20)$ as including strains that exhibit an extraordinary range of $T_{\max }$, from less than $25^{\circ} \mathrm{C}$ to more than $37^{\circ} \mathrm{C}$. The previously reported widespread occurrence of $C$. albidus var. albidus in soil could result either from the presence of local races which have evolved adaptive temperature characteristics or from mistakened attributions to this species. Therefore, an examination of the levels of DNA reassociation between the type strain of $C$. albidus var. albidus and phenotypically similar strains isolated from soils of the Antarctic cold desert (the McMurdo Dry Valleys, also referred to as the Ross Desert), seemed likely to be valuable in assessing the role of habitat temperature in yeast species identification. The Antarctic strains were conspecific neither with $C$. albidus var. albidus nor with the phenotypically similar species Filobasidium floriforme Olive. Four Antarctic biotypes are described in this paper as Cryptococcus antarcticus sp. nov., and a fifth biotype is described as Cryptococcus albidosimilis sp. nov.

\section{MATERIALS AND METHODS}

Abbreviations. $T_{\max }$, maximum growth temperature(s); $\mathrm{G}+\mathrm{C}$, guanine plus cytosine; DBB, diazonium blue $\mathrm{B}$.

Yeast strains. $C$. albidus var. albidus ATCC $10666^{\mathrm{T}}(=$ NRRL Y $-1400^{\mathrm{T}}=$ CBS 142$)(\mathrm{T}=$ type strain $)$, Cryptococcus vishniacii Vishniac and Hempfling ATCC $36649^{\mathrm{T}}$ (= NRRL

\footnotetext{
* Corresponding author.
}

$\mathrm{Y}-17208^{\mathrm{T}}=\mathrm{CBS}$ 7110), Filobasidium floriforme ATCC $22367^{\mathrm{T}}$ (= NRRL Y-7453 $\left.{ }^{\mathrm{T}}=\mathrm{CBS} 6241\right)$, and strains MYSW A834-66Y604/52 (= NRRL Y-17459 = ATCC $76661=$ CBS 7689), MYSW A812-20bY648/52 (= NRRL Y-17467), MYSW A834-66Y699/61 (= NRRL Y-17460 = ATCC 76662 $=$ CBS 7688), MYSW A812-20bY693/64 ${ }^{\mathrm{T}}$ (= NRRL Y-17461 ${ }^{\mathrm{T}}=$ ATCC $76663^{\mathrm{T}}=$ CBS $7687^{\mathrm{T}}$ ), MYSW A81220bY718/67 (= NRRL Y-17386 = ATCC 76664 = CBS 7690), MYSW A834-66Y748/67 (= NRRL Y-17462), and MYSW A823-2Y761/70 ${ }^{\mathrm{T}}\left(=\right.$ NRRL Y-17463 ${ }^{\mathrm{T}}=$ ATCC $76863=$ CBS 7711) from the collection of one of us (H.S.V.) were isolated and/or maintained by using previously described methods (12, 27-29). The MYSW strain designations indicate the geographic origin (A for Antarctic), the austral summer during which the soil sample was collected (for example, 812 for the 1981-1982 summer), the collection site (site 2, 66, or 20; see below), the type of isolate ( $Y$ for yeast), the isolate number within that type, and the biotype (the number after the shill) to which the isolate was assigned after preliminary characterization. Sand and gravel were collected at depths of 0 to $2 \mathrm{~cm}$ at site 2, which was on the east slope of Linnaeus Terrace $\left(77^{\circ} 36^{\prime} \mathrm{S}, 161^{\circ} 08^{\prime} \mathrm{E}\right)$, a plateau at an altitude of ca. $1,600 \mathrm{~m}$ under Mt. Oliver and above the Wright Valley. This location had been used for several seasons as a camping area. Sites 20 and 66 were in University Valley $\left(77^{\circ} 52^{\prime} \mathrm{S}\right.$, $160^{\circ} 40^{\prime} \mathrm{E}$ ), a hanging valley which is off Beacon Valley and is headed by a glacier that gives rise to an occasional melt stream, which at the times of collection was only an empty drainage channel. Sample 20b consisted of damp sand that was collected 1 to $3 \mathrm{~cm}$ below the surface at the top of the talus slope, and the sample at site 66 consisted of gravel and dry soil aggregates that were collected 0 to $3 \mathrm{~cm}$ below the surface, nearer the open end of Beacon Valley in the dry drainage channel.

Physiological characterization. Strains were characterized morphologically by using standard methods (25) and physiologically by using previously described methods $(12,28)$ 
that were considered more suitable for most Antarctic strains than the standard methods described by van der Walt and Yarrow (25). Where the $\mathrm{pH}$ of a substrate is given below, it is the $\mathrm{pH}$ of a $10 \%$ stock solution that was used to prepare media. Colony color on certain substrates was characterized by using the system of Kornerup and Wanscher (16). Vitamin requirements were also examined in liquid medium (Y-2 medium base supplemented with $1.0 \mathrm{mM}$ $\mathrm{NH}_{4} \mathrm{Cl}$ and $5.0 \mathrm{~g}$ of glucose per liter) that was shaken at ca. $140 \mathrm{rpm}$ in a refrigerated water bath (model G76; New Brunswick Scientific Co.) held at $15^{\circ} \mathrm{C}$. Halotolerance was determined under the same cultural conditions as vitamin requirements, except that we used a liquid medium containing $0.5 \times$ Y-2 medium base to which we added $2.0 \mathrm{mM}$ monosodium glutamate, $2.0 \mathrm{mM} \mathrm{NH}_{4} \mathrm{Cl}, 400 \mu \mathrm{g}$ of thiamine hydrochloride per liter, $500 \mathrm{mg}$ of yeast extract per liter and $5.0 \mathrm{~g}$ of glucose per liter; this medium was inoculated from exponentially growing precultures containing no $\mathrm{NaCl}$ or 1.0 $\mathrm{M} \mathrm{NaCl}$. Growth rates were calculated from optical densities at $650 \mathrm{~nm}$, as measured after any required period of adaptation. No adaptation period was required after osmotic downshift. Osmotic upshift required a period of adaptation that was roughly proportional to the added osmolarity. For example, strain MYSW A812-20bY648/52 required ca. 0.6 generation to reach its maximal growth rate when $0.6 \mathrm{M}$ $\mathrm{NaCl}$ was added and ca. 1.25 generations when $1.2 \mathrm{M} \mathrm{NaCl}$ was added. $T_{\max }$ was determined in a low-temperature incubator (model 815; Precision Scientific Co.) and in a standard Thelco Precision model 6 incubator by using slants of $1.0 \%$ glucose- $0.5 \%$ peptone- $0.3 \%$ yeast extract-1.8\% agar medium that were inoculated with a suspension of cells that had been grown at a temperature which was $5^{\circ} \mathrm{C}$ below the test temperature (26). Growth was tested at $15,20,25$, 30,35 , and $40^{\circ} \mathrm{C}$.

The fatty acid compositions of cells grown at $14^{\circ} \mathrm{C}$ on $1.0 \%$ glucose- $0.5 \%$ peptone- $0.3 \%$ yeast extract- $1.8 \%$ agar medium were analyzed by Microbial ID, Inc., Newark, Del.

DNA purification and characterization. Cultures were grown in 1.2-liter batches of liquid media in 2,800-ml Fernbach flasks which were incubated in a Psychrotherm incubator (New Brunswick Scientific Co.) that was held at $13^{\circ} \mathrm{C}$ and shaken at $140 \mathrm{rpm}$. The medium used for the type cultures of $C$. albidus and $F$. floriforme contained $0.5 \%$ peptone, $0.3 \%$ yeast extract, and $1.0 \%$ glucose. For the Antarctic strains, $0.2 \%$ peptone, $0.1 \%$ yeast extract, and $1.0 \%$ glucose were used. Cells were harvested during exponential growth by centrifugation, washed once with sterile deionized distilled water, and freeze-dried. Freeze-dried cells were broken in a Braun homogenizer with the aid of $0.5-\mathrm{mm}$ glass beads and then extracted with a $\mathrm{pH} 8.4$ solution containing $0.2 \mathrm{M}$ Tris, $0.25 \mathrm{M} \mathrm{NaCl}, 25 \mathrm{mM}$ EDTA, and $0.5 \%$ sodium dodecyl sulfate. The concentration of sodium perchlorate in the solution was then adjusted to $1 \mathrm{M}$, and the solution was treated with an equal volume of chloroform-isoamyl alcohol $(24: 1)$ with shaking at $100 \mathrm{rpm}$ for 1.5 to $2.25 \mathrm{~h}$. The DNA was spooled after cold $\left(-20^{\circ} \mathrm{C}\right)$ ethanol (1.3 to 1.5 volumes) was added to the supernatant aqueous phase obtained by centrifugation. The spooled DNA was dissolved in $0.1 \times \mathrm{SSC}(1 \times \mathrm{SSC}$ is $0.15 \mathrm{M} \mathrm{NaCl}$ plus $0.015 \mathrm{M}$ sodium citrate) (21), enough $\mathrm{NaCl}$ and sodium citrate were added to make the solution $1.0 \times \mathrm{SSC}$, and the preparation was incubated at $25^{\circ} \mathrm{C}$ and $100 \mathrm{rpm}$ with $\alpha$-amylase $\left(0.4 \mathrm{mg} \mathrm{ml}^{-1}\right)$ and pancreatic RNase $\left(320 \mu \mathrm{g} \mathrm{ml}^{-1}\right)$ for 1.5 to $2 \mathrm{~h}$. Pronase $\left(160 \mu \mathrm{g} \mathrm{ml}^{-1}\right)$ was then added before additional incubation for 1 to $2 \mathrm{~h}$, after which treatment with chloroform-isoamyl alcohol $(24: 1)$ and spooling were re- peated as described above. The second spools were redissolved and purified to hyperchromicities of 31 to $35 \%$ by ultracentrifugation in a $\mathrm{CsCl}$ solution $\left(1.55 \mathrm{~g} \mathrm{ml}^{-1}\right)$ in a Beckman model TL-100 centrifuge at $100,000 \mathrm{rpm}$ for $17 \mathrm{~h}$ at $20^{\circ} \mathrm{C}$. The $\mathrm{G}+\mathrm{C}$ content was calculated from melting curves obtained with a Gilford model 250 recording spectrophotometer equipped with a model 2527 thermoprogrammer. The same equipment was used for reassociation experiments performed as previously described (18). Levels of DNA sequence similarity, expressed as percentages of relatedness, were calculated from duplicate experiments by using the equation of Seidler and Mandel (22). In our experience the average of duplicate determinations was within $5 \%$ of the levels of relatedness determined when more replicates were used.

\section{RESULTS AND DISCUSSION}

The phenotypic characteristics of the type strain of $C$. albidus var. albidus (strain ATCC 10666) and of the Antarctic strains are shown in Table 1 . All of the Antarctic isolates were tentatively identified as $C$. albidus var. albidus or $F$. floriforme (17). Failure to utilize glucosamine $\mathbf{N}$ and the numerous variable characteristics of $C$. albidus $(3,20)$ resulted in this identification for the Antarctic isolates. Yeasts belonging to more than one biological species have been placed in C. albidus var. albidus; strains that are capable and incapable of productive mating with the sexual types of $F$. floriforme have been included in this taxon (19). Therefore, in this study we compared organisms only with the type strain of $C$. albidus var. albidus by using data generated with the medium that is more suitable for Antarctic indigenes (27, $28,31)$. C. albidus var. albidus ATCC $10666^{\mathrm{T}}$ gave more positive assimilation results on commercial (Difco) yeast nitrogen base (25) than on the basal medium used for Antarctic yeasts.

The results of spectrophotometric DNA reassociation experiments are shown in Table 2. None of the Antarctic strains was conspecific with $C$. albidus or $F$. floriforme. The strains belonging to more psychrophilic biotypes (biotypes $52,61,64$, and 67) were conspecific, presumably indigenous exemplars of a new species described below. The strains belonging to these biotypes were isolated from the soil of a remote valley, and their presence was not ephemeral; the biotype 52 and 67 strains were each isolated from collections in two different years and at two different sites in University Valley. A biotype 70 strain was isolated only once, from soil at the Linnaeus Terrace camp site area. The indigenity of this isolate, a mesophile obtained from a location that had been subjected to prolonged human presence and activity, is questionable. Since the biotype 70 strain is not conspecific with the other Antarctic isolates, it is described below as a member of a new species.

Description of Cryptococcus antarcticus Vishniac and Kurtzman sp. nov. Cryptococcus antarcticus (ant'arc.ti.cus. L. adj. antarcitus, opposite the North Star, referring to the Antarctic habitat).

Latin diagnosis of Cryptococcus antarcticus Vishniac and Kurtzman. Coloniae in agaro colore candido aut cremeo, sed aliquae interdum flavescentes, politae et paululae mucosae. In mediis liquidiis pellicula nulla, annulus exigue, et sedimentum lente formantur. Cellulae ovoideae, maturae et mediae (ex agaro) $7.5 \times 4.0 \mu \mathrm{m}$, cum capsulis exiguis, e situ cicatricis natalis iterumque generatae. Nec pseudomycelium nec mycelium formatur. Non generant sed per modo blastico 


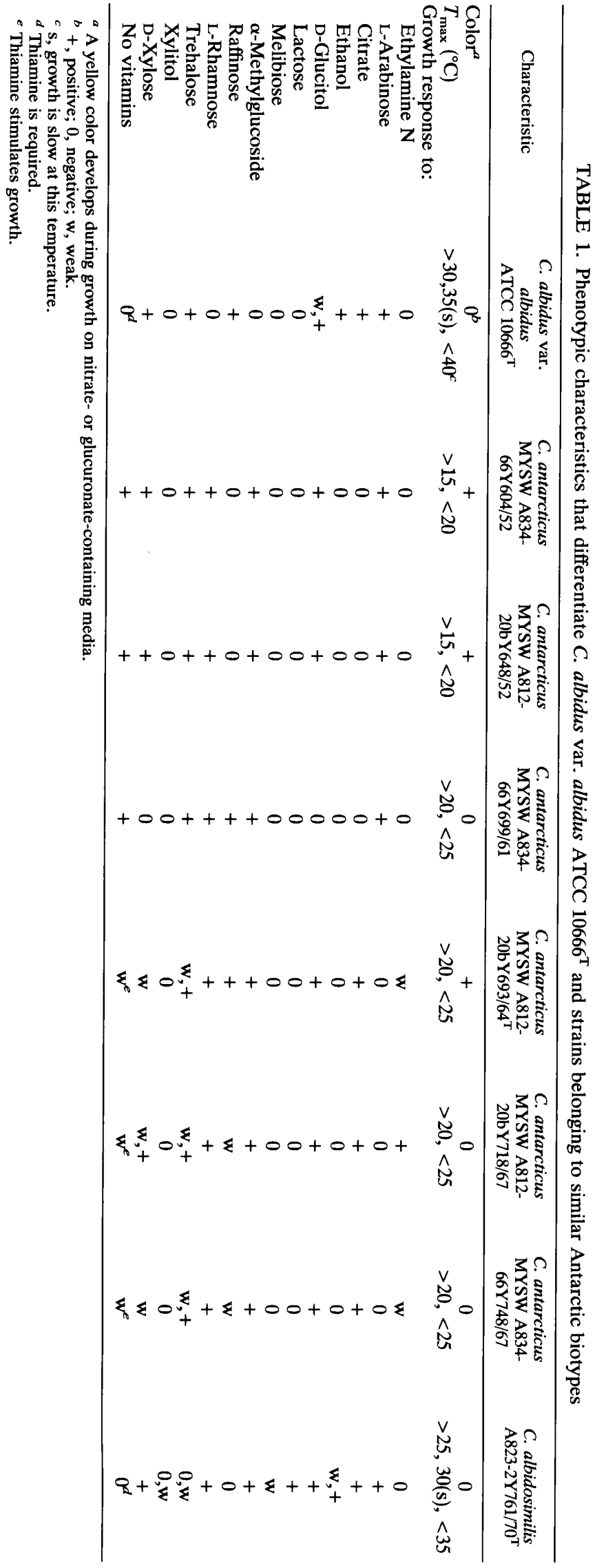

TABLE 2. Levels of DNA complementarity among Cryptococcus species isolated from Antarctic soils and phenotypically similar yeast species

\begin{tabular}{lccc}
\hline & \multicolumn{3}{c}{ \% DNA reassociation with: } \\
\cline { 2 - 4 } Strain & $\begin{array}{c}\text { C. antarcticus } \\
\text { MYSW A812- } \\
\text { 20bY693/64 }\end{array}$ & $\begin{array}{c}\text { C. albidus } \\
\text { ATCC } \\
10666^{\mathrm{T}}\end{array}$ & $\begin{array}{c}\text { F. floriforme } \\
\text { ATCC } \\
22367^{\mathrm{T}}\end{array}$ \\
\hline C. antarcticus & 73 & & 10 \\
$\quad$ MYSW A834-66Y604/52 & 102 & & 0 \\
MYSW A834-66Y699/61 & 103 & 14 & 0 \\
$\begin{array}{l}\text { MYSW A812-20bY693/64 } \\
\text { MYSW A812-20bY718/67 }\end{array}$ & 9 & 18 & 5 \\
$\begin{array}{l}\text { C. albidosimilis MYSW } \\
\text { A823-2Y761/70 }\end{array}$ & -2 & 6 & \\
C. vishniacii ATCC 36649 & -2 & & \\
\hline
\end{tabular}

asexuali, calore $4^{\circ} \mathrm{C}$ usque ad gradum minorem quam 20 aut $25^{\circ} \mathrm{C}$.

Non fermentat. Assimilat L-arabinosum (nonnullae gentes), cellobiosum, acidum citratum ( $\mathrm{pH}$ 6.0) (nonnullae gentes), D-glucitolum (nonnullae gentes), acidum D-gluconicum ( $\mathrm{pH}$ 5.8), acidum D-glucuronicum ( $\mathrm{pH}$ 5.5), myo-inositolum, acidum 2-ketogluconicum, maltosum, mannitolum, melezitosum, $\alpha$-methylgulcosidosum, raffinosum (nonnullae gentes), L-rhamnosum, salicinum, amylosum (sine agarum hyalinum faciens), acidum succinicum ( $\mathrm{pH}$ 5.5), sucrosum, trehalosum, et D-xylosum (nonnullae gentes). Non assimilat L-arabinitolum, D-arabinosum, erythritolum, ethanolum, galacititolum, D-galactosum, D-glucosaminum ( $\mathrm{pH} 6.0$ ), glycerolum, DL-acidum lacticum ( $\mathrm{pH}$ 6.0), lactosum, melibiosum, ribitolum, D-ribosum, L-sorbosum, et xylitolum. Cadaverino, ethylamino (nonnullae gentes), L-lysino, nitratoque utit, sed nec creatinino nec glucosamino. Crescit sine vitamines, sed nonnullae gentes valde cum thiamino crescent.

Amylosum formatum est. Cum cycloheximido $0.01 \%$ non crescit. DBB respondet. G+C, $55 \mathrm{~mol} \%$.

Typus BPI, cultura sicca, designat stirpem typicam. Isolata cultura viva MYSW A812-20bY693/64 (= ATCC 76663 $=$ CBS $7687=$ NRRL Y-17461) e solo, Universitas Vallis, exemplum unum pictum est.

C. antarcticus colonies growing on agar are slightly mucous and shining white to cream colored; the colonies of some strains become dirty yellow (Methuen color standard 4B4 [16]) when they assimilate glucuronate or utilize nitrate $\mathrm{N}$. Growth is very poor in unagitated liquid media; the organisms slowly produce a scanty annulus and a little sediment. Cells are ovoid, possess a scanty capsule, and are functionally monopolar, budding repeatedly from the site of the primary bud scar. The average size of mature (nonbudding) cells taken from an agar slant is 7.5 by $4.0 \mu \mathrm{m}$. Sexual reproduction has not been observed. Neither mycelium nor pseudomycelium is formed. Growth occurs at temperatures ranging from $4^{\circ} \mathrm{C}$ to more than $15^{\circ} \mathrm{C}$ but less than $20^{\circ} \mathrm{C}$ or less than $25^{\circ} \mathrm{C} ; T_{\max }$ is a strain characteristic (Table 1). The species is DBB positive and has a $\mathrm{G}+\mathrm{C}$ content of $55 \mathrm{~mol} \%$.

The species does not ferment. The following substrates are assimilated as sole carbon sources: L-arabinose (some strains), cellobiose, citrate (pH 6.0; some strains), D-glucitol (some strains), gluconate ( $\mathrm{pH} 5.8)$, glucuronate $(\mathrm{pH} 5.5)$, myo-inositol, 2-ketogluconate (hemicalcium salt; $\mathrm{pH}$ not adjusted), maltose, mannitol, melezitose, $\alpha$-methylglucoside, raffinose (some strains), L-rhamnose, salicin, soluble 


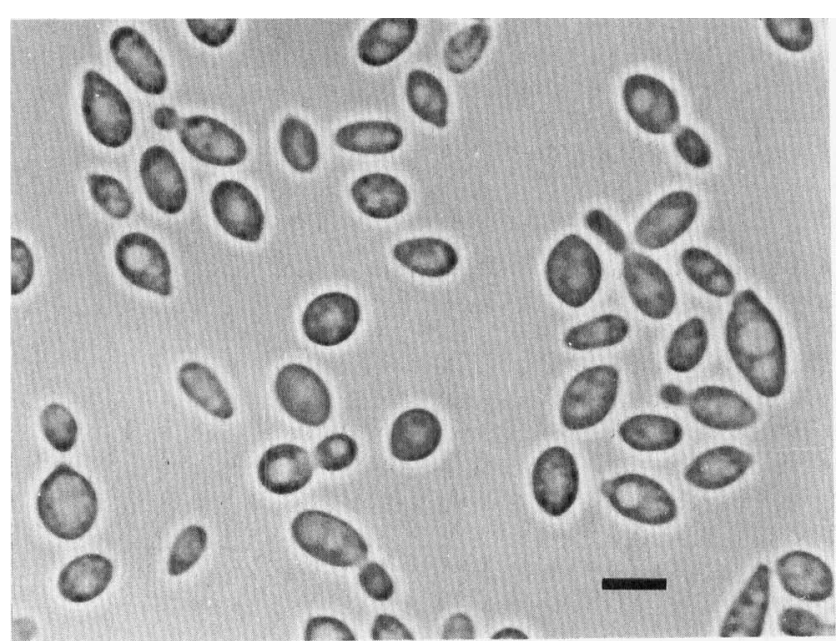

FIG. 1. Photomicrograph of vegetative cells of the $C$. antarcticus type strain after incubation for 3 days on yeast-malt agar at $15^{\circ} \mathrm{C}$. $\mathrm{Bar}=5 \mu \mathrm{m}$.

starch (without clearing of the medium), succinate ( $\mathrm{pH} 5.5$ ), sucrose, trehalose, and xylose (some strains).

Not assimilated as sole carbon sources are L-arabinitol, D-arabinose, erythritol, ethanol, galactitol, D-galactose, D-glucosamine ( $\mathrm{pH} 6.0)$, glycerol, DL-lactate $(\mathrm{pH} 6.0)$, lactose, melibiose, ribitol, D-ribose, L-sorbose, and xylitol.

The nitrogen sources utilized include cadaverine, ethylamine (some strains), L-lysine, and nitrate; neither creatinine nor glucosamine is utilized as a nitrogen source. Vitamins are not required, although some strains are strongly stimulated by thiamine. Amylose is produced. Growth is inhibited by $100 \mu \mathrm{g}$ of cycloheximide per $\mathrm{ml}$.

The type strain of $C$. antarcticus Vishniac and Kurtzman sp. nov. is strain MYSW A812-20bY693/64 (= ATCC 76663 $=$ CBS $7687=$ NRRL Y-17461), which was isolated from soil from University Valley, South Victoria Land, Antarctica (Fig. 1).

C. antarcticus is considered basidiomycetous by virtue of its positive DBB reaction and its conformation to the description of the anamorphic genus Cryptococcus Vuillemin as proposed by Fell et al. (7). Although Table 1 shows more than one difference between $C$. antarcticus and the type strain of C. albidus var. albidus, the variation in the physiological characteristics of the biotypes assigned to $C$. antarcticus is such that this species can be distinguished from C. albidus var. albidus as currently described $(3,20)$ only by the fact that it has a $T_{\max }$ of less than $25^{\circ} \mathrm{C}$ or on the basis of nuclear DNA dissimilarity (Table 2). The biotypes can be identified on the basis of differences in utilization of ethylamine $\mathrm{N}, \mathrm{L}$-arabinose, D-glucitol, and D-xylose in combination with color development on nitrate $N$, differences which may also distinguish them from $C$. albidus var. albidus on this taxonomic level.

Description of Cryptococcus albidosimilis Vishniac and Kurtzman sp. nov. Cryptococcus albidosimilis (al'bid.o.sim.il.is. L. adj. albidosimilis, like albidus, referring to the similarity of this species to C. albidus).

Latin diagnosis of Cryptococcus albidosimilis Vishniac and Kurtzman. Coloniae in agaro colore candido, politae et mucosae. In mediis liquidiis pellicula nulla, annulus exigue, et sedimentum lente formantur. Cellulae ovoideae, maturae et mediae (ex agaro) $6.6 \times 4.9 \mu \mathrm{m}$, cum capsulis, e situ cicatricis natalis iterumque generatae. Nec pseudomycelium nec mycelium formatur. Non generant sed per modo blastico asexuali, calore maxime $30^{\circ} \mathrm{C}$ (maiore quam $25^{\circ} \mathrm{C}$, lente $30^{\circ} \mathrm{C}$, minore quam $35^{\circ} \mathrm{C}$.

Non fermentat. Assimilat L-arabinosum, cellobiosum, acidum citratum ( $\mathrm{pH} 6.0$ ), ethanolum (interdum lente), D-glucitolum, acidum D-gluconicum ( $\mathrm{pH} 5.8$ ), acidum D-glucuronicum ( $\mathrm{pH}$ 5.5), myo-inositolum, acidum 2-ketogluconicum, lactosum, maltosum, mannitolum, melezitosum, melibiosum (lente), $\alpha$-methylglucosidosum, L-rhamnosum, salicinum, amylosum (sine agarum hyalinum faciens), acidum succinicum ( $\mathrm{pH}$ 5.5), sucrosum, D-xylosumque et interdum lente trehalosum xylitolumque. Non assimilat L-arabinitolum, D-arabinosum, erythritolum, galactitolum, D-galactosum, D-glucosaminum ( $\mathrm{pH}$ 6.0), glycerolum, DL-acidum lacticum (pH 6.0), raffinosum, ribitolum, D-ribosum, L-sorbosumque et interdum trehalosum xylitolumque. Cadaverino, L-lysino, nitratoque utit, sed nec creatinino nec ethylamino nec glucosamino. Non crescit sine vitamines, thiaminum requirens.

Amylosum formatum est. Cum cycloheximido $0.01 \%$ non crescit. DBB respondet. G+C, $55 \mathrm{~mol} \%$.

Typus BPI, cultura sicca, designat stirpem typicam. Isolata cultura viva MYSW A823-2Y761/70 (= NRRL Y-17463 = ATCC $76863=$ CBS 7711) e solo, Terratio Linnaeo, exemplum duum pictum est.

C. albidosimilis colonies growing on agar are mucous and shining white. Growth is very poor in unagitated liquid media; the organisms slowly produce a scanty annulus and a little sediment. Cells are ovoid, encapsulated, and functionally monopolar, budding repeatedly from the site of the primary bud scar. The average size of mature (nonbudding) cells taken from an agar slant is 6.6 by $4.9 \mu \mathrm{m}$. Sexual reproduction has not been observed. Neither mycelium nor pseudomycelium is formed. The maximum growth temperature is $30^{\circ} \mathrm{C}$; growth occurs slowly at this temperature, vigorously at $25^{\circ} \mathrm{C}$, and not at all at $35^{\circ} \mathrm{C}$. The species is DBB positive and has a $\mathrm{G}+\mathrm{C}$ content of $55 \mathrm{~mol} \%$.

The species does not ferment. The following substrates are assimilated as sole carbon sources: L-arabinose, cellobiose, citrate ( $\mathrm{pH} \mathrm{6.0)}$, ethanol (sometimes weakly), D-glucitol, gluconate ( $\mathrm{pH} 5.8)$, glucuronate ( $\mathrm{pH} 5.5)$, myo-inositol, 2-ketogluconate (hemicalcium salt; $\mathrm{pH}$ not adjusted), lactose, maltose, mannitol, melezitose, melibiose (weakly), $\alpha$-methylglucoside, L-rhamnose, salicin, soluble starch (without clearing of the medium), succinate ( $\mathrm{pH} 5.5$ ), sucrose, and xylose. Sometimes trehalose and xylitol are weakly assimilated as sole carbon sources.

Not assimilated as sole carbon sources are L-arabinitol, D-arabinose, erythritol, galactitol, D-galactose, D-glucosamine ( $\mathrm{pH} 6.0)$, glycerol, DL-lactate $(\mathrm{pH} 6.0)$, lactose, raffinose, ribitol, D-ribose, L-sorbose, and sometimes trehalose and xylitol.

The nitrogen sources utilized include cadaverine, L-lysine, and nitrate; creatinine, ethylamine, and glucosamine are not utilized as nitrogen sources. Thiamine is required. Amylose is produced. Growth is inhibited by $100 \mu \mathrm{g}$ of cycloheximide per ml.

The type strain of $C$. albidosimilis Vishniac and Kurtzman sp. nov. is strain MYSW A823-2Y761/70 (= NRRL Y-17463 $=$ ATCC $76863=$ CBS 7711), which was isolated from soil from Linnaeus Terrace, Wright Valley, South Victoria Land, Antarctica (Fig. 2).

C. albidosimilis is considered basidiomycetous by virtue of its positive $\mathrm{DBB}$ reaction and conformation to the description of the anamorphic genus Cryptococcus Vuillemin (7). This species is distinguished most readily from $C$. antarcti- 


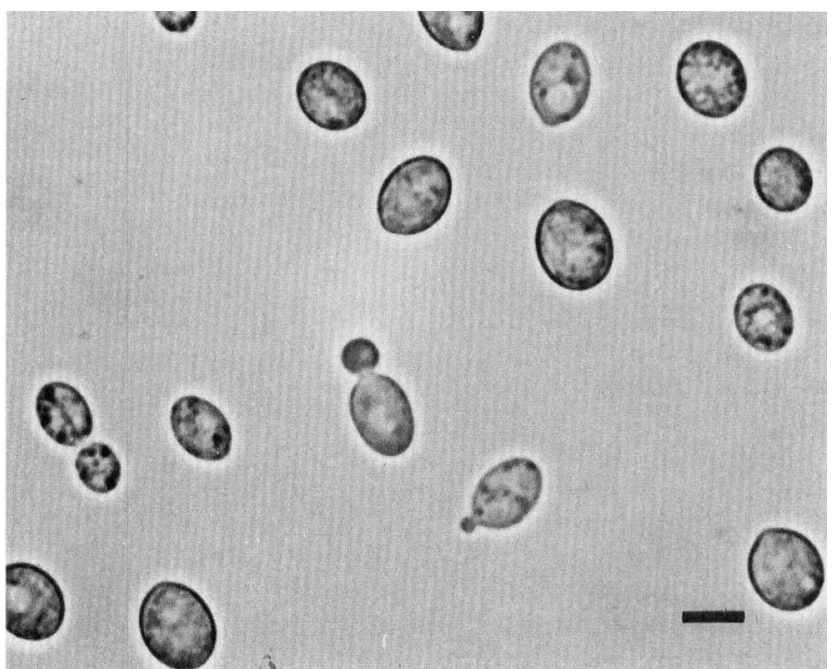

FIG. 2. Photomicrograph of vegetative cells of the $C$. albidosimilis type strain after incubation for 3 days on yeast-malt agar at $15^{\circ} \mathrm{C}$. Bar $=5 \mu \mathrm{m}$.

cus by its positive lactose assimilation and from the type strain of $C$. albidus var. albidus by its $T_{\max }$, but can be distinguished from $C$. albidus var. albidus as currently described $(3,20)$ only on the basis of nuclear DNA dissimilarity.

Whole-cell fatty acid composition has been used increasingly for identification of ascomycetous yeasts $(2,14,15)$, although it has been used for few basidiomycetous yeasts (23). Table 3 shows the fatty acid compositions of $C$. albidus var. albidus, $C$. vishniacii, the $C$. antarcticus biotypes, and $C$. albidosimilis. The $C$. antarcticus biotypes (with biotype 52 as an outlier) clustered separately from $C$. albidosimilis, and both Antarctic species were well separated from $C$. albidus var. albidus in the discriminant analysis performed by Microbial ID, Inc. $C$. antarcticus and $C$. vishniacii were not separated in this discriminant analysis, although these species lack significant DNA similarity (Table 2). The relative amounts of unsaturated fatty acids are inversely related to $T_{\max }$ for $C$. antarcticus, $C$. albidosimilis, and $C$. albidus var. albidus, implying greater adaptation to low environmental temperatures by the more psychrophilic species $(8,10)$.

The taxonomic separation of the Antarctic Cryptococcus isolates from $C$. albidus both confirms the importance of $T_{\max }$ range in yeast species identification and contributes to bringing $C$. albidus into conformity with van Uden's (26) rule that $T_{\max }$ does not vary by more than $5^{\circ} \mathrm{C}$ among biovars of a species. $C$. albidus is poorly delimited; no isolates with significant levels of DNA similarity to the type strain have been shown to have $T_{\max }$ at or below $30^{\circ} \mathrm{C}$. The remaining $T_{\max }$ variation $\left(>30\right.$ to $>37^{\circ} \mathrm{C}$ ) in isolates attributed to this species will require further study of strains isolated from other habitats. Does authentic $C$. albidus occur in Antarctica? The soil samples which were examined in the laboratory of one of us (H.S.V.) did not yield any C. albidus. The absence of other studies of DNA similarity and the confusion inherent in using phenotypic data for identification make this question unanswerable at the present time. There is no reason to believe that other Antarctic isolates that were placed in this taxon $(1,4-6,9,24)$ were correctly assigned. The psychrophilic $\left(T_{\max },<20^{\circ} \mathrm{C}\right)$ isolates of Atlas et al. (1) may have been conspecific with $C$. antarcticus.

The availability of liquid water also appears to have played a role in the evolution of $C$. antarcticus. $C$. antarcticus was isolated only from soil samples that were obtained from the vicinity of a dry melt stream bed in a glaciated hanging valley and was not isolated from the numerous samples of more permanently arid soils ccntaining yeasts belonging to the $C$. vishniacii complex (indigenous inhabitants of highland soils in other parts of the McMurdo Dry Valleys) or from samples obtained from the bed of a running melt stream. While soil sample A812-20b was among the samples with the lowest salt contents, sample A834-66 had one of the highest salt burdens (total major cation burden, $53.02 \mu \mathrm{eq}$ ) of the fertile soils examined (13). The occasional availability of melt stream water could obviously lower soil solution osmolality to the point (above ca. $-3.5 \mathrm{MPa}$ ) that allowed growth and could easily provide more than the $25 \mu \mathrm{l}$ of liquid per $\mathrm{g}$, allowing further colonization by McMurdo Dry Valley yeasts $(13,32)$. These direct effects of melt stream water do not explain the apparent confinement of $C$. antarcticus to the habitat from which it was isolated. Furthermore, the $C$. antarcticus biotypes are more halotolerant (growth rates estimated to fall to 0 between 1.45 and $1.70 \mathrm{M} \mathrm{NaCl}$ ) than the type strain of $C$. vishniacii (growth rate estimated to fall to 0 at $1.2 \mathrm{M}$ $\mathrm{NaCl}$ ), although they are less halotolerant than the type strain of $C$. albidus var. albidus (growth rate estimated to fall to 0 at ca. $1.83 \mathrm{M} \mathrm{NaCl}$ ) (Fig. 3). The energetic burden which is patently imposed by additional mineral salts suggests that melt stream water offers a more important advantage, the

TABLE 3. Fatty acid compositions

\begin{tabular}{|c|c|c|c|c|c|c|c|c|c|c|c|}
\hline \multirow[b]{2}{*}{ Strain } & \multicolumn{11}{|c|}{ Fatty acid composition (\%) } \\
\hline & $14: 0$ & $16: 0$ & $\begin{array}{l}16: 0 \\
2 \mathrm{OH}\end{array}$ & $\begin{array}{c}16: 1 \text { cis }-9 \\
(\omega-7)\end{array}$ & $18: 0$ & $\begin{array}{c}18: 1 \text { cis-9 } \\
(\omega-9)^{a}\end{array}$ & $\begin{array}{l}\text { 18:1 cis-9 } \\
\text { DMA }^{b}\end{array}$ & $\begin{array}{l}\text { 18:1 cis-11 } \\
\text { DMA }\end{array}$ & $18: 2$ cis $-9,12$ & $\begin{array}{c}20: 2 \text { cis-11,14 } \\
(\omega-6)\end{array}$ & $\mathrm{C} 20 \mathrm{NOH}$ \\
\hline C. albidus ATCC $10666^{\mathrm{T}}$ & 0.22 & 17.66 & & 0.15 & 4.99 & 36.38 & 0.87 & 0.27 & 39.16 & & 0.29 \\
\hline $\begin{array}{l}\text { C. albidosimilis MYSW } \\
\text { A823-2Y761/70 }\end{array}$ & & 11.81 & & & 2.64 & 34.96 & 0.81 & & 49.77 & & \\
\hline C. antarcticus & & & & & & & & & & & \\
\hline MYSW A834-66Y604/52 & 0.16 & 10.47 & & & 2.82 & 54.44 & 0.74 & 0.19 & 31.19 & & \\
\hline MYSW A834-66Y699/61 & & 5.95 & & & 1.06 & 39.15 & 1.24 & & 52.21 & 0.39 & \\
\hline MYSW A812-20bY693/64 & & 7.78 & 0.23 & & 0.42 & 48.97 & 0.88 & 0.30 & 41.43 & & \\
\hline MYSW A812-20bY718/67 & & 6.28 & & & 0.39 & 43.69 & 0.87 & 0.31 & 48.46 & & \\
\hline C. vishniacii ATCC $36649^{\mathrm{T}}$ & & 7.38 & & & 0.86 & 46.89 & 1.24 & 0.27 & 43.09 & & 0.27 \\
\hline
\end{tabular}

\footnotetext{
${ }^{a}$ Sum of unresolved peaks attributable to $18: 1$ cis-9 $(\omega-9)$ and/or 18:1 ( $\left.\omega-8\right)$.

${ }^{b}$ Sum of unresolved peaks attributable to $18: 1 \mathrm{cis}-9$ dimethyl acetal and/or an unknown fatty acid having an equivalent chain length 18.218 . DMA,
} dimethylacetal. 


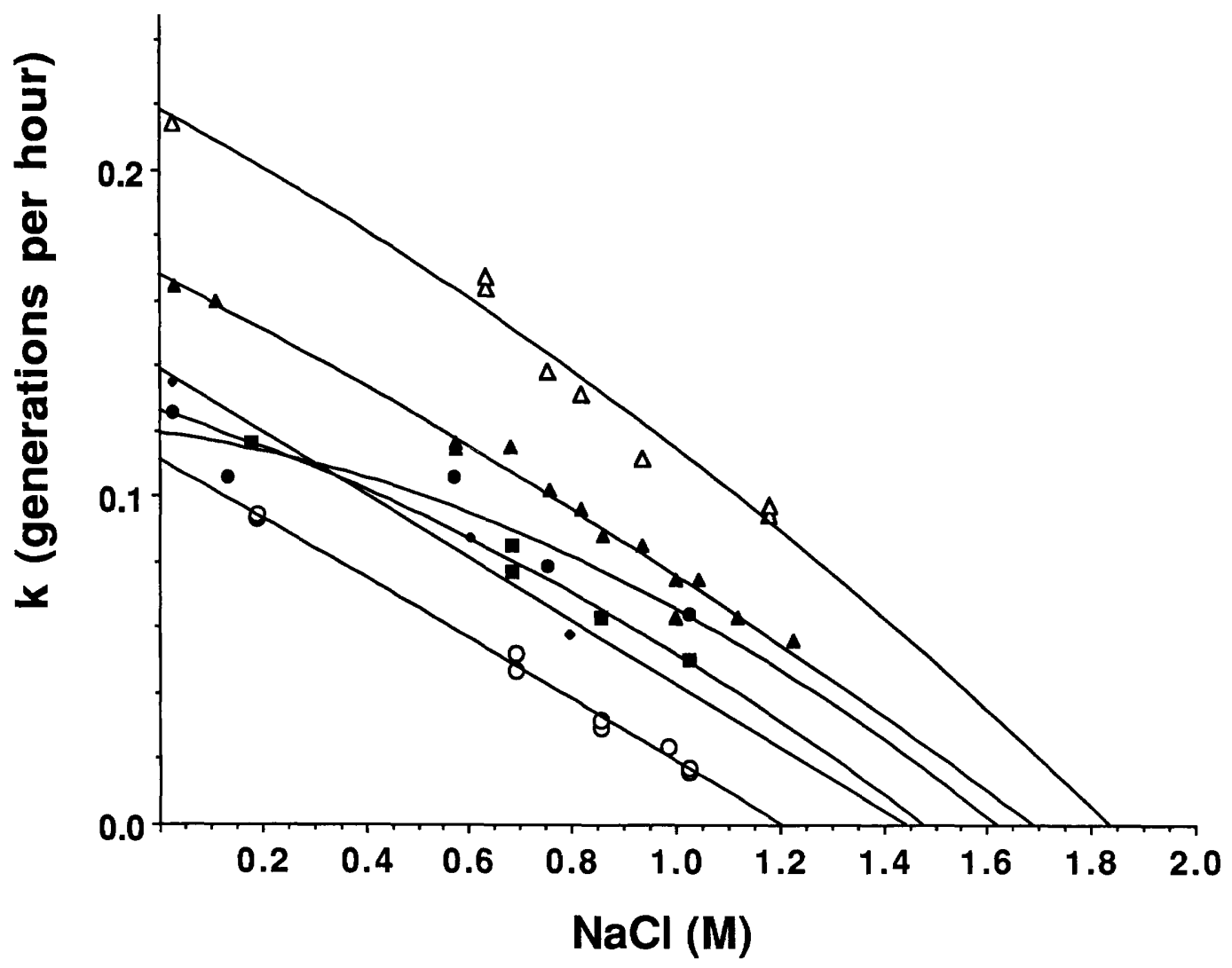

FIG. 3. Growth rates of $C$. albidus var. albidus $(\triangle)$, C. vishniacii $(\bigcirc)$, and $C$. antarcticus MYSW A834-66Y604/52 ( $(\Delta)$, MYSW A834-66Y699/61 (@), MYSW A812-20bY693/64 $(\boldsymbol{\square})$, and MYSW A834-20bY718/67( $)$ in the presence of $\mathrm{NaCl}$ at $15^{\circ} \mathrm{C}$ with agitation at 140 rpm. Curves were fitted by using Cricket Graph version 1.2. Most of the variances $\left(r^{2}\right)$ ranged from 0.970 to 0.995 ; the exception was the biotype 61 strain, for which $r^{2}$ was 0.885 .

provision of additional substrate by a more diverse community, a community that includes primary producers (33). More halotolerant microbes (e.g., Halomonas spp., which are capable of growth in the presence of $20 \% \mathrm{NaCl}[>3.4 \mathrm{M}$ $\mathrm{NaCl}$ ) occur in the Antarctic saline lakes, which derive their nutrients not only from glacial melt streams but also from lacustrine microalgal populations and vertebrate excreta (11). All of the $C$. antarcticus biotypes assimilate myoinositol and mannitol, and some are stimulated by thiamine; both of these characteristics indicate adaptation to a more diverse community than that in which the $C$. vishniacii yeasts (which assimilate no polyols and grow maximally in the absence of growth factors) live. Halotolerance is roughly proportional to maximal growth rate (Fig. 3), suggesting that C. antarcticus should outgrow $C$. vishniacii when adequate substrate is available but should be outgrown by $C$. albidus in still richer environments. While we can never guarantee that the maximal growth rate observed is indeed truly maximal, it is noteworthy that the halotolerance of the type strain of $C$. vishniacii in these experiments was not significantly different from that reported previously for C. vishniacii var. asocialis in a somewhat different medium at a temperature $5^{\circ} \mathrm{C}$ lower $(13,32)$. Therefore, $C$. antarcticus may be confined to the habitat from which it was isolated primarily by the degree of mesotrophy which defines its niche.

\section{ACKNOWLEDGMENT}

We thank Microbial ID, Inc., Newark, Del., for fatty acid composition data and analysis of these data.

\section{REFERENCES}

1. Atlas, R. M., M. E. Di Menna, and R. E. Cameron. 1978. Ecological investigations of yeasts in Antarctic soils. Antarct. Res. Ser. 30:27-34.

2. Augustyn, O. P. H., and J. L. F. Kock. 1989. Differentiation of yeast species, and strains within a species, by cellular fatty acid analysis. I. Application of an adapted technique to differentiate between strains of Saccharomyces cerevisiae. J. Microbiol. Methods 10:9-23.

3. Barnett, J. A., R. W. Payne, and D. Yarrow. 1990. Yeasts: characteristics and identification, 2nd ed. Cambridge University Press, Cambridge.

4. Cameron, R. E. 1971. Antarctic soil microbial and ecological investigations, p. 137-189. In L. O. Quam and H. D. Porter (ed.), Research in the Antarctic. American Association for the Advancement of Science, Washington, D.C.

5. Cameron, R. E., J. King, and C. N. David. 1970. Soil microbial ecology of Wheeler Valley, Antarctica. Soil Sci. 109:110-120.

6. Di Menna, M. E. 1966. Yeasts in Antarctic soils. Antonie van Leeuwenhoek J. Microbiol. 32:29-38.

7. Fell, J. W., C. P. Kurtzman, and K. J. Kwon-Chung. 1989. Proposal to conserve Cryptococcus (fungi). Taxon 38:151-152.

8. Golubev, W. I., M. T. Smith, G. A. Poot, and J. L. F. Kock. 1989. Species delineation in the genus Nadsonia Sydow. Antonie van Leeuwenhoek 55:369-382. 
9. Goto, S., J. Sugiyama, and H. Iizuka. 1969. A taxonomic study of Antarctic yeasts. Mycologia 61:748-774.

10. Herbert, R. A. 1986. The ecology and physiology of psychrophilic microorganisms, p. 1-23. In R. A. Herbert and G. A. Codd (ed.), Microbes in extreme environments. Academic Press, London.

11. James, W. R., S. J. Dobson, P. D. Franzmann, and T. A. McMeekin. 1990. Halomonas meridiana, a new species of extremely halotolerant bacteria isolated from Antarctic saline lakes. Syst. Appl. Microbiol. 13:270-278.

12. Klingler, J. M., and H. S. Vishniac. 1988. A contribution of Antarctic ecology to yeast systematics. Polarforschung 58:8392.

13. Klingler, J. M., and H. S. Vishniac. 1988. Water potential of Antarctic soils. Polarforschung 58:231-238.

14. Kock, J. L. F. 1988. Chemotaxonomy and yeasts. S. Afr. J. Sci. 84:735-740.

15. Kock, J. L. F., P. M. Lategan, P. J. Botes, and B. C. Viljoen. 1985. Developing a rapid statistical identification process for different yeast species. J. Microbiol. Methods 4:3-4.

16. Kornerup, A., and J. H. Wanscher. 1967. Methuen handbook of colour. Methuen \& Co. Ltd., London.

17. Kreger-van Rij, N. J. W. 1984. Key to species and genera not requiring characteristics of sexual reproduction, p. 974-989. In N. J. W. Kreger-van Rij (ed.), The yeasts-a taxonomic study. Elsevier Science Publishing, Amsterdam.

18. Kurtzman, C. P., M. J. Smiley, C. J. Johnson, L. J. Wickerham, and G. B. Fuson. 1980. Two new and closely related heterothallic species, Pichia amylophila and Pichia mississippiensis: characterization by hybridization and deoxyribonucleic acid reassociation. Int. J. Syst. Bacteriol. 30:208-216.

19. Kwon-Chung, K. J., and J. W. Fell. 1984. Filobasidium Olive, p. 483-491. In N. J. W. Kreger-van Rij (ed.), The yeasts-a taxonomic study. Elsevier Science Publishing, Amsterdam.

20. Rodrigues de Miranda, L. 1984. Cryptococcus Kützing emend. Phaff et Spencer, p. 845-872. In N. J. W. Kreger-van Rij (ed.), The yeasts-a taxonomic study. Elsevier Science Publishing, Amsterdam.

21. Sambrook, J., E. F. Fritsch, and T. Maniatis. 1989. Molecular cloning, 2nd ed. Cold Spring Harbor Laboratory Press, Cold Spring Harbor, N.Y.

22. Seidler, R. J., and M. Mandel. 1971. Quantitative aspects of deoxyribonucleic acid renaturation: base composition, state of chromosome replication, and polynucleotide homologies. J. Bacteriol. 106:608-614.

23. Smit, E. J., J. P. J. v.d. Westhuizen, J. L. F. Kock, and P. M. Lategan. 1987. A yeast identification method: the influence of culture age on the cellular long-chain fatty acid composition of three selected basidiomycetous yeasts. Syst. Appl. Microbiol. 10:38-41.

24. Soneda, M. 1961. On some yeasts from the Antarctic region. Biol. Results Jpn. Res. Exped. 15:3-10.

25. van der Walt, J. P., and D. Yarrow. 1984. Methods for the isolation, maintenance, classification and identification of yeasts, p. 45-104. In N. J. W. Kreger-van Rij (ed.), The yeasts-a taxonomic study. Elsevier Science Publishing, Amsterdam.

26. van Uden, N. 1984. Temperature profiles of yeasts. Adv. Microb. Physiol. 25:195-251.

27. Vishniac, H. S. 1983. An enation system for the isolation of Antarctic yeasts inhibited by conventional media. Can. J. Microbiol. 29:90-95.

28. Vishniac, H. S. 1985. Yeast biomass in Ross Desert (dry valley) soils: evaluation of quantitation methods and sample transport effects. Antarct. J. U. S. 19:174-176.

29. Vishniac, H. S. 1985. Cryptococcus socialis sp. nov. and Cryptococcus consortionis sp. nov., Antarctic basidioblastomycetes. Int. J. Syst. Bacteriol. 35:119-122.

30. Vishniac, H. S. 1987. Psychrophily and the systematics of yeast-like fungi, p. 389-402. In G. S. De Hoog, M. T. Smith, and A. C. M. Weijman (ed.), The expanding realm of yeast-like fungi. Elsevier Science Publishing, Amsterdam.

31. Vishniac, H. S., and S. Baharaeen. 1982. Five new basidioblastomyceteous yeast species segregated from Cryptococcus vishniacii emend. auct., an Antarctic yeast species comprising four new varieties. Int. J. Syst. Bacteriol. 32:437-445.

32. Vishniac, H. S., and J. Klingler. 1986. Yeasts in the Antarctic desert, p. 46-51. In F. Megusar and M. Gantar (ed.), Perspectives in microbial ecology. Proceedings of the Fourth International Symposium on Microbial Ecology. Slovene Society for Microbiology, Ljubljana, Yugoslavia.

33. Wynn-Williams, D. D. 1990. Ecological aspects of Antarctic microbiology. Adv. Microb. Ecol. 11:71-146. 